\title{
Employees Perception of Human Capital Practices, Employee's Productivity, and Company Performance
}

\author{
Audy Thuda ${ }^{a}$, Junita Sari ${ }^{\mathrm{b}}$, Anita Maharani ${ }^{\mathrm{c} *}$ \\ ${ }_{a, b, c}$ Bina Nusantara University, Jakarta \\ anita.maharani@binus.edu
}

\begin{abstract}
This study aims to find out whether there is an influence between human capital practices and productivity on company performance. The theoretical approach raised in this study is about human capital, productivity, and company performance. The research method approach carried out in this study is quantitative, namely by regression testing, and previously testing the quality of the instrument through validity and reliability tests. The results obtained are that the practice of human capital and productivity does affect the performance of the company. So it is recommended that companies that are the samples of this study can consider policies that can support company performance through the practice of human capital and support for employee productivity, although there are still many other factors that affect company performance.
\end{abstract}

Article Info

- Received : May 24, 2019

- Revised : August 24, 2019

- Published : September 15, 2019

- No. Pages : 240-250

- DOI : 10.33019/ijbe.v3i3.188

- JEL : J24, L25

- Keywords : human capital, employees' productivity, company performance

\section{Introduction}

The paradigm is shifted, from human resources to human capital, and within decades human capital has increasingly become the central role in achieving organizational success. This called as challenges and is faced by companies as there are several issues as follows; retention, employee engagement and provision of benefits and compensation. This issue encourages modern companies to design their human capital to be more strategic and measurable. To optimize human capital, it is encouraged to an organization to perform a better corporate performance through the productivity of its employees. However, employee's productivity is always closely related to company performance, and for this reason, companies need to devote their resources and attention to human capital policies that effectively will contribute to company performance.

Company's performance has a priority as a measure of the success of a business entity. To become superior performance there are several underlying criteria. Porter \& Tanner (2014) once mentioned that there is a Baldrige Model, which states that human capital is one of the criteria for organizations to achieve superior performance. According to Tessema (2014), at the organizational level, human capital plays an important role in strategic planning to determine how companies create their competitive advantage. Therefore, company's 
performance is influenced by the implementation of human capital policies, and since human capital is one of the most valuable and important assets of an organization, it helps companies to grow and achieve their goals more effectively and efficiently (Cloud \& Sarfraz, 2013). Samad (2013) concluded that the factors in human capital positively have a relationship with company performance and have a significant impact. The challenge above if it is not managed will certainly be a problem for the company. Employees must be the most important part of the company, especially in the process of implementing its business strategy (Ding \& Cai, 2018). The assessment of company performance based on human capital is an interesting thing that needs to be developed by companies because employees are one of the main components of intellectual capital (intangible assets) owned by the company. According to Mayo (2000), measuring the performance of companies from a financial perspective is very accurate, but actually what will be the basis for driving the value of finance is human capital with all the knowledge, ideas and innovations it has. That is why this study intends to identify the impact of the management strategy of human capital on company performance so that it can help top management and practitioners of human resources in improving the performance of their companies.

The company business besides facing challenges in the field of the population as described above will also face the impact of digital disruption. In the current era of industrial revolution 4.0, the use of technology is increasingly becoming an important requirement while at the same time giving an impact (Latief, 2018). Prayogo (2018) reports that Bank Mandiri responded to this by implementing automation in almost all fields, from opening accounts to credit applications. The statement indicated that there would be a reduction in the workforce at Bank Mandiri which used to do work manually to be replaced with a machine. Besides that, Rafie (2018) reported that the banking industry is currently experiencing sluggishness, especially banks in BUKU 1 and 2 categories which are pressured by large banks. So that the empowerment of internal resources is a hot issue amid the sluggish industry. In Indonesia, FIFGROUP a finance company from the Astra group is one example of a company that has successfully implemented human resources policies. As a winner of the 2018 Indonesia Human resources Award (Antara News, 2018), FIFGROUP is consistently one of the market leaders in the finance industry. World calibre companies like Facebook Inc., Starbucks Corp. and Google, which is included in the Top 10 World's Top Company for HR (Workforce.com, 2018), shows that great attention to human resources supports the company to continue to succeed even consistently as a market leader.

The increasing challenges of companies facing the external environment, among others, address the increasing problems of employment and the impact of digital disruption and growth of the banking industry. This is very interesting to study because human resources as the main internal factor in the company are the only hope to boost the performance of the company amid the increasingly complex threats and challenges of the external environment. This research is expected to be able to measure the extent of the impact of the implementation of human resources policies on company performance, in this case, Bank Sulselbar and SulutGo Bank. This article focuses on the impact of implementing human resources' practices on corporate performance through surveys, and it was conducted at the South and West Sulawesi Regional Development Bank (Bank Sulselbar) headquartered in Makassar \& North Sulawesi Regional Development Bank and Gorontalo (Bank SulutGo) headquartered in Manado. In this article, there are two main issues, first, the extent of the impact of human resources policies on employee productivity, and second, how employee productivity may contribute to improving company performance. 
This study aims to examine the impact of the implementation of human resources policies on company performance. To achieve the research objectives, the research questions below are expected to be able to explain the purpose of the research held. That is to determine the impact of the implementation of human resources policy on employee productivity. This study intends to analyze the impact of human resources policies at Bank Sulselbar and SulutGo Bank on company performance. The research was conducted at the Head Office and Branches in both Makassar and Manado.

\section{Literature Reviews}

As stated earlier, the discussion of human capital policy is a major concern to address the company's challenges to the problems of employment, digital disruption and increasingly fierce business competition. This study focuses on the impact of policy implementation, especially the Human resources strategy on company performance. Companies need to achieve strategic organizational human resource (HR) management goals as well as other strategic research in this field (Cania, 2014).

\section{Human Capital Policy}

According to Carniero \& Heckman (2004), the framework for human resources policy emphasizes the need to recognize the dynamic nature of the process of human accumulation and the multiplicity of actors and institutions that determine human resources investment. The identification of the dynamic nature of employees and the role of the company in optimizing employee roles is highly dependent on how the management strategies of $\mathrm{HC}$ will work effectively through implementing policies. The Strategic HRM by Noe et al (2017) is interpreted as a pattern of allocation of human resources and activities that enable the organization to achieve its objectives.

Ding et al (2018) define strategic HRM as integration between strategy theory and human resource management theory. When the discussion enters the core strategic approach to management, strategic human resources is then interpreted to be; how to achieve and maintain competitive advantage as a "core competency" of a company (Zommorodian, 2014). Boon et al (2018) explained that strategic HRM \& strategic HC are two research fields which together emphasize the importance of human resources. Furthermore, according to Boon et al, research on strategic HRM focuses on systems and individuals who handle HR, while strategic HC examines humans themselves. For this reason, this study does not directly explain the impact of $\mathrm{HC}$ management strategies on company performance, but first identifies the impact on employee productivity. Human resources concept in this study will focus on how the company formulates its strategy in managing human resources and aligns it with the company's strategy.

Bagieńska (2015), the measurement of human resources may be divided into four groups;

1. Condition: a qualitative-quantitative measure of the staffing structure

2. Expenditure: expenditure on human resources and its staffing structure

3. Development: qualitative and quantitative information on employee development investment

4. Effect: measurement of benefit efficiency and employee development

Furthermore, Fitz-enz (2009) explains that in measuring human capital there are three approaches as follows;

1. Measurement of human capital related to its contribution to company goals

2. Related to the impact of business processes 
3. Relating to value-added

\section{Employee's Productivity}

The basis for increasing employee productivity is the result of identifying gap analysis of organizational skills that the company intervenes through training strategies (Abomeh \& Peace, 2015). Productivity can be defined as the output given by employees to the company.

Sauerman (2016) suggests that in measuring employee productivity, it must fulfil the following elements:

1. Objectivity: measurement must be objective.

2. Availability: measurements must be available at the employee level, not only at the team or company level.

3. Comparability: tasks and measurements must apply equally to all workers and periods.

4. Quality and control (Quality \& controllability): employees must have an adequate share of the results, for example; can choose the level according to his ability.

Employee productivity has a stake in improving the performance of the company. For this reason, companies that seek to improve their competitive advantage through their employees must be able to manage the behaviour and work outcomes of their employees (Noe et al, 2017).

\section{Company's Performance}

Companies generally have goals, both those in the vision and mission as well as those expected by the owner of the company. This is confirmed by Alchian \& Demsetz (Cania, 2014) that organizational performance is defined as a comparison between the value produced by a company and the expected value the owner receives from the company. Furthermore, Cania (2014) explains that several studies have subjectively evaluated the performance of the company, through indicators such as; employee satisfaction, customer satisfaction, perceptions of executives, attendance, employee commitment, and other aspects of behaviour. Another study references objective measures for evaluating company performance, such as financial and market indicators. From the description above it can be concluded that there is no general theory that pays attention to organizational performance because researchers use indicators and different variables to examine this.

Based on how to measure it, Kaplan and Norton (1992) classify company performance into two categories, namely:

1. Financial Performance.

The company's financial performance is the performance outlined in the annual report. All forms of company activities to improve key financial indicators that are recorded systematically and measured using the standard method and then outlined in the periodic report are called financial performance.

2. Non-financial Performance.

Definition of non-financial performance that refers to company activities carried out to improve key indicators on human resources, structural capital, and customer capital. This performance can be seen from the added value of intangible assets owned by the company. So to find out the overall performance of the company can be seen from the accumulation of financial performance and non-financial performance.

The measurement of company performance in the study eludes perceived financial performance and non-financial performance. 


\section{HC Policy Relations with Corporate Performance}

Human resources are one of the company's most important resources to maintain competitive organizational performance. The company's ability to compete competitively depends on the accumulation of knowledge and capabilities of its employees. For this reason, the company's ability to compete in a very competitive market through the development of value-added products and services, depends on its employees (knowledge and ability), in other words, depends on the effectiveness of human resources (Dubra, 2010).

In examining its relationship with company performance, HC policy can be seen from its performance through 'performance outcomes' in HR management by Dyer \& Reeves (1995) classified as follows:

1. HR-related outcomes: such as turnover, absenteeism, job satisfaction, commitment, employees

2. Organizational outcomes: such as productivity, quality, service, efficiency, customer satisfaction.

3. Financial accounting outcomes: such as profit, sales, return on assets (ROA), return on investment (ROI).

4. Capital market outcomes, such as market share, stock prices, growth (Boxall, Purcell and Wright, 2007).

From the description of the literature review described above, the research that will examine the impact of HC policy implementation on employee productivity then observes the effect of employee productivity on improving company performance. From various kinds of literature, most directly link human resources with company performance. Now the researchers first examined the relationship with employee productivity as a mediating variable, then proceeded to examine the relationship between employee productivity and company performance. The relationship of these variables forms the theoretical framework of this research as a model for building hypotheses as illustrated below.

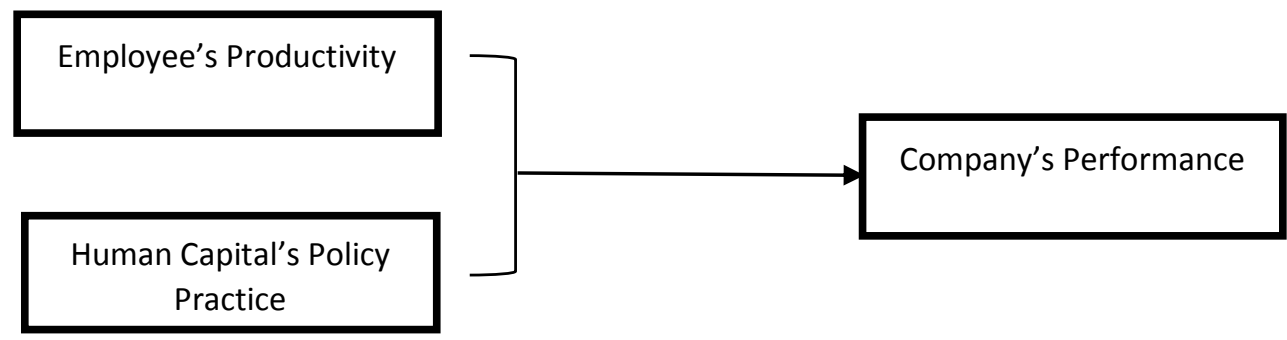

Figure 1. Research Model

Based on the literature review described and the theoretical framework above, the researcher formulates the following hypothesis:

$\mathrm{H} 1$ : there is an influence of human resources policy practices on the company's performance

$\mathrm{H} 2$ : there is an influence of employee productivity on the company's performance

$\mathrm{H} 3$ : there is an influence of human resources policy practices and employee's productivity on the company's performance

\section{Research Methods}

This research seeks to understand phenomena that happened between independent variable to the dependent variable. Therefore, this research may be categorized as causal research. The population refers to all groups of people who are the research objectives (Sekaran \& Bougie, 
2016: 22), in this case, Bank Sulselbar employees and SulutGo Bank located in the Head Office and surrounding branches. Samples are part of the number and characteristics of the population (Sugiyono 2013). The results of the analysis of the sample are used to estimate the characteristics of the entire population (Levine et al, 2014). The population consisted of Bank Sulselbar employees in the head office and branches in Makassar City totalling 215 people, so the number of samples was determined based on the Slovin formula of 140 respondents. While the population of Bank SulutGo employees at the Head Office and branches in the city of Manado and its surroundings number 600. Therefore, the number of samples is 240 respondents.

This research uses primary data, on the other words, this research collects data directly from respondents, that has already filled in questionnaires. Therefore, in other words, data collection techniques used in this research is survey method. The survey method is a method of collecting primary data by taking a certain number of samples from a population by filling out a questionnaire (Jogiyanto, 2013). The survey was conducted in October 2018, through the distribution of questionnaires at the Head Office of Bank Sulselbar and Branch Offices in the City of Makassar and the Head Office of SulutGo Bank and Branch Offices in the City of Manado and its surroundings.

Based on the relationship between human resources policy and company performance, the measurement dimensions for the implementation of human capital policies and employee's productivity that would affect company's performance can be explained as follows.

\begin{tabular}{|c|c|c|}
\hline Variables & Sources & Dimensions \\
\hline \multirow[t]{4}{*}{$\begin{array}{l}\text { Human Capital } \\
\text { Practice }\end{array}$} & $\begin{array}{l}\text { Kucharpíkováa, A., } \\
\text { Tokarpíkováa, E., \& } \\
\text { Blaškováa, M. (2015) }\end{array}$ & $\begin{array}{l}\text { (1) hiring the right talent, (2) orienting } \\
\text { employee to the organization, (3) making a } \\
\text { new employee feel comfortable, (4) training } \\
\text { employees to constantly upgrade their skills, } \\
\text { (5) retaining employees, (6) making } \\
\text { employees self-sufficient and prepare them for } \\
\text { adverse conditions. }\end{array}$ \\
\hline & Samad, S. (2013) & $\begin{array}{l}\text { (1) training and development, (2) knowledge, } \\
\text { (3) skills, (4) creativity, (5) competency and } \\
\text { (6)employee's attitude }\end{array}$ \\
\hline & $\begin{array}{l}\text { Alnachef, T., \& Ahsan } \\
\text { Alhajjar, A. (2017). }\end{array}$ & $\begin{array}{l}\text { (1) learning and education, (2) experience \& } \\
\text { expertise, (3) innovation and creation }\end{array}$ \\
\hline & Mayo, A., (2000) & $\begin{array}{l}\text { (1) individual capability, (2) individual } \\
\text { motivation, } \\
\text { organizational } \\
\text { ergatectiveness }\end{array}$ \\
\hline
\end{tabular}

Amelia, Manuti \& Palma, According to DiBernardino, a human capital Pasquale. (2014) strategy consists of four major elements:

(1) talent; vacancy, staffing configuration, new hire quality, turnover, internal job fills, succession pool coverage, training, 


\begin{tabular}{|c|c|c|}
\hline & & $\begin{array}{l}\text { performance } \\
\text { (2) rewards; compensation, incentive, } \\
\text { employee benefits, and perquisites. } \\
\text { (3) culture; employee engagement scores, } \\
\text { employee exit survey results, client } \\
\text { satisfaction ratings } \\
\text { (4) HR service; staffing, organization } \\
\text { development, compensation and benefits, } \\
\text { training, employee satisfaction, employee } \\
\text { relations, and HR technology }\end{array}$ \\
\hline \multirow[t]{2}{*}{ Productivity } & $\begin{array}{l}\text { Sumual, T., Kawulur, A. } \\
\text { F., Manaroinsong, T. } \\
\text { (2017) }\end{array}$ & 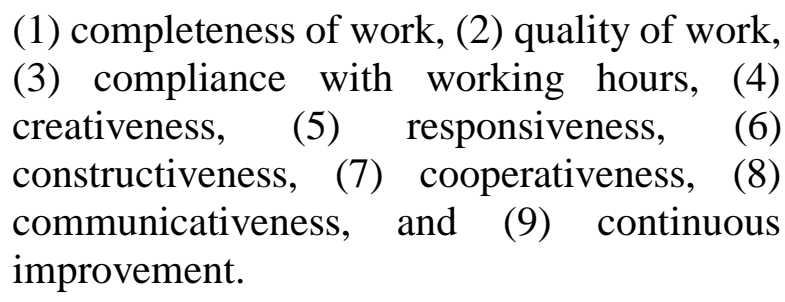 \\
\hline & Beaton, D. et al (2009) & $\begin{array}{l}\text { (1) absenteeism, (2) at work productivity loss } \\
\text { or presenteeism }\end{array}$ \\
\hline \multirow[t]{3}{*}{$\begin{array}{l}\text { Company's } \\
\text { Performance }\end{array}$} & Kaplan \& Norton (1992) & $\begin{array}{l}\text { Company performance is categorized as } \\
\text { financial and non-financial }\end{array}$ \\
\hline & $\begin{array}{l}\text { Iddagoda \& } \\
\text { Gunawardana (2017) }\end{array}$ & $\begin{array}{l}\text { Employee engagement as one aspect of human } \\
\text { capital has a positive impact on the company's } \\
\text { non-financial performance; sales growth or } \\
\text { sales growth }\end{array}$ \\
\hline & Dyer \& Reeves (1995) & $\begin{array}{l}\text { HR-related outcomes: such as turnover, } \\
\text { absenteeism, job satisfaction, employee } \\
\text { commitment. Organizational outcomes: such } \\
\text { as productivity, quality, service, efficiency, } \\
\text { customer satisfaction }\end{array}$ \\
\hline
\end{tabular}

Quality of instruments was measured using validity and reliability method, and in this case, the statistical tool used to analyze the data obtained from data collection is SPSS. The technique used to test the validity of the instrument is to look at the corrected total correlation score to check the validity of the instrument, while to check the reliability of the instrument items is to see the Cronbach alpha value if the item is deleted. The second value obtained from the category is compared with the value of the $\mathrm{R}$ table, whereas, calculated valid and reliable the compilation of the values of the two categories is greater than the $\mathrm{R}$ table, which in this case is $0.1002(\mathrm{~N}=383)$, and based on the results obtained, all items are valid and reliable.

\section{Results}

This section will explain the values that support the hypothesis of this study. Starting from the first hypothesis, Hypothesis test of this research will use regression test and see the value of $R$ Square. Then, between two research objects will be compared referring to the value of the $\mathrm{R}$ Square. The results obtained are certainly interesting to discuss further. In this study, we want to raise about how employees perceive human capital, corporate performance and employee 
productivity practices, which are taken in two state-owned banks in Indonesia, namely Bank SulselBar and Bank SulutGo. These two banks are banks that owned by local governments in Indonesia, namely the SulselBar Bank owned by the South Sulawesi regional government, while Bank SulutGo is owned by the North Sulawesi regional government.

H1: there is an influence of human resources policy practices on company's performance

\begin{tabular}{cc}
\hline Sample(s) & R Square \\
\hline Bank Sulselbar & 0,270 \\
\hline Bank Sulutgo & 0,419 \\
\hline
\end{tabular}

Based on the table above, human resources' policy practice in Bank Sulselbar contributed 27 percent in explaining the changes that occur in employee productivity, while the remaining 73 percent is explained by other variables outside the model. While at Bank SulutGo it was found that human resources had a contribution of 41,9 percent in explaining the changes that occurred in employee productivity, while the remaining 58,1 percent was explained by other variables outside the model. Therefore, this result shows that although hypothesis 1 as "there is the influence of the implementation of human resources policy on employee productivity" is accepted, it indicates, that there are factors that cannot be explained by only this variable.

$\mathrm{H} 2$ : there is an influence of employee productivity on company's performance

\begin{tabular}{cc}
\hline Sample(s) & R Square \\
\hline Bank Sulselbar & 0,252 \\
\hline Bank Sulutgo & 0,47 \\
\hline
\end{tabular}

Based on the table above, in Bank Sulselbar case, human resources' policy practice contributed 25,2 percent in explaining the changes that occur in employee productivity, while the remaining 74,8 percent is explained by other variables outside the model. While at Bank SulutGo it was found that human resources had a contribution of 47 percent in explaining the changes that occurred in employee productivity, while the remaining 53 percent was explained by other variables outside the model. Therefore, this result shows that although hypothesis 1 as "there is an influence of employee productivity on company's performance" is accepted, it indicates, that there are factors that cannot be explained by only this variable.

H3: there is an influence of human resources policy practices and employee's productivity on company's performance

\begin{tabular}{cc}
\hline Sample(s) & R Square \\
\hline Bank Sulselbar & 0,319 \\
\hline Bank Sulutgo & 0,503 \\
\hline
\end{tabular}

Based on the table above, in Bank Sulselbar case, human capital's policy practice has a contribution of 31,9 percent in explaining the changes that occur in employee productivity, while the remaining 68,1 percent is explained by other variables outside the model. While at Bank SulutGo it was found that human resources had a contribution of 50,3 percent in explaining the changes that occurred in employee productivity, while the remaining 49,7 percent was explained by other variables outside the model. Therefore, this result shows that although hypothesis 3 as "there is an influence of human resources policy practices and 
employees' productivity on company's performance" is accepted, it indicates, that there are factors that cannot be explained by only this variable.

Based on simple linear regression test with the independent variables of productivity and human capital practices on company performance applies to both of companies, it is known that, the value of R Square obtained is 0.522 (Appendix), or in other words, the magnitude of the effect caused by human capital and productivity practices on company performance can be explained as 52, 2 percent, while 47.8 percent are caused by other variables that have not been studied in this study. However, if referring to the beta value, it is known that the magnitude of the influence caused by productivity and human capital practices on company performance can be illustrated in the following formula

$$
\mathrm{Y}=2,49+0,471 \mathrm{X} 1+0,279 \mathrm{X} 2
$$

where $\mathrm{X} 1$ is human capital and $\mathrm{X} 2$ is productivity, it can be explained that every increase in the practice of human capital will have an effect of 0.147 times and an increase in productivity will have an effect of 0.279 times. In summary, the effect caused by productivity and human capital on company performance is positive and significant. Based on the results of the regression test, all hypotheses are proven, where there is an influence of the independent variable on the dependent variable. However, the interesting thing is that all of these effects are relatively small in terms of the regression results. What can be indicated from this result is that there are still other independent variables besides the independent variables raised in this study which are considered to affect the dependent variable. For example, about the influence of human capital practices on company performance, the results obtained can be attributed to the two banks, that in addition to human capital practices there are still other things that affect company performance. If it is associated with the opinion of Fitz-enz (2009) which states that there is a measure of human capital, then the results of this study can be considered to confirm this opinion, although the effect of this practice is not large.

\section{Conclusion and Recommendation}

The purpose of this study is to determine the impact of the implementation of human resources policies on company performance. Based on the results of the study prove human capital policy and productivity affect company's performance. This study has several limitations, namely, the components of human capital used are only six aspects, so there are still other factors likely to have an influence on company performance such as; leadership and work culture. This research collects data to only two banks, and differences in research results and conclusions may be achieved if studies are conducted on different study objects using different components of human resources. In general, human capital and productivity policies have a positive influence on company performance. In terms of suggestions, since it was found that there are still factors that cannot be explained through variables used, there is a possibility of using other variables, and since results show that human capital and productivity affect company's performance, this may lead to managerial implications within the companies as they may apply a supportive environment and implement policies that relate and support human capital and productivity.

\section{References}

1) Abomeh, O. S., \& Peace, N. N., (2015). Effects of Training on Employees Productivity in Nigeria Insurance Industry. British Journal of Economics, Management \& Trade, ISSN: 2278-098X, Vol.: 7, Issue.: 3 . 
2) Alnachef, T., \& Ahsan Alhajjar, A., (2017). Effect of Human Capital on Organizational Performance: A Literature Review. International Journal of Science and Research (IJSR). 6, 1154 $-1158$.

3) Amelia, Manuti \& Palma, Pasquale. (2014). Why Human Capital is Important for Organizations. Palgrave Macmillan, pp. 119-120.

4) Bagieńska, A. (2015). Measurement and Analysis of the Efficiency of Human Capital in A Small Enterprises in Poland. e-Finance: Financial Internet Quarterly, ISSN 1734-039X, University of Information Technology and Management, Rzeszów, Vol. 11, Iss. 2, pp. 1-9, http://dx.doi.org/10.14636/1734-039X11201.

5) Bank Sulselbar. (2018). Annual Report 2017. PT. Bank Pembangungan Daerah Sulselbar. Makasar. Retrieved from https ://banksulselbar.co.id/ download/ laporan_tahunan/ 2017.

6) Beaton, Dorcas; Bombardier, Claire; Escorpizo, Reuben; Zhang, Wei; Lacaille, Diane; Boonen, Annelies; Osborne, Richard H; Anis, Aslam H.; Strand, C. Vibeke; Tugwell, Peter S. (2009). Measuring Worker Productivity: Frameworks and Measures. The Journal of Rheumatology 2009; 36:9; DOI:10.3899/jrheum.090366.

7) Boon, C., Eckardt, R., Lepak, D. P., \& Boselie, P., (2018). Integrating strategic human capital and strategic human resource management, The International Journal of Human Resource Management, 29:1, 34-67, DOI: 10.1080/09585192.2017.1380063.

8) Boxall, P \& Purcell, J. (2003). Strategy and Human Resource Management. Industrial \& Labor Relations Review. 57. 10.1108/00251740310479368.

9) Cania, L., (2014). The Impact of Strategic Human Resource Management on Organizational Performance. Economia. Seria Management Economia. Seria Management, 17(2), 374-383.

10) Ding, J., \& Cai, X. (2018). Study on the Impact of Strategic Human Resource Management on Enterprise Performance. International Journal of Human Resource Studies, 8(3), Pages 60-68. doi:http://dx.doi.org/10.5296/ijhrs.v8i3.13087.

11) Dubra, I. (2010). Human Capital Impact On the Enterprise Competitiveness. Publications of International Conference, No. 1 (26), p. 53-57.

12) Dyer, L. \& Reeves, T. (1995). Human Resources Strategies and Firm Performance: What Do We Know and Where Do We Need to Go? International Journal of Human Resource Management 6(3), pp 656-670.

13) Fitz-Enz, J. (2009). The ROI of Human Capital: Measuring The Economic Value of Employee Performance. Second Edition. New York: Amacom.

14) Jogiyanto. (2013). Pedoman Survei Kuisioner: Mengembangkan Kuisioner, Mengatasi Bias dan Meningkatkan Respon. Jogjakarta: BPFE.

15) Kaplan, R. S. and D. P. Norton (1992). The Balanced Scorecard - Measures That Drive Performance. Harvard Business Review 70(7/8): 172-180.

16) Levine, D. M., Stephan, D. F. And Szabat, K. A. (2014). Statistics for Managers Using Microsoft Excel $-7^{\text {th }}$ ed. USA. Pearson Education, Inc.

17) Mayo, A. (2000). The Role of Employee Development in The Growth of Intellectual Capital. Personal Review, Vol. 29, No. 4. http://www.emerald-library.com.

18) Noe, R. A., Hollenbeck, J. R., Gerhart, And B., Wright, P. M., (2017). Human Resource Management: Gaining A Competitive Advantage, 10e. Boston: McGraw-Hill/Irwin.

19) Porter, L. \& Tanner, S. (2004). Assessing Business Excellence. $2^{\text {nd }}$ Edition. Oxford: Elsevier Butterworth-Heinemann.

20) Prayogo, C. (Ed). (2018, 14 May). Menakar Dampak Disrupsi Ekonomi Digital di Indonesia. Retrieved $22^{\text {th }}$ July 2018 from https ://www.wartaekonomi.co.id /read180842/ menakar-dampakdisrupsi-ekonomi-digital-di-indonesia.html.

21) Rafie, B. T. (Ed). (2018, 8 July). Kinerja Bank BUKU 1 Dan 2 Lesu, Bankir Revisi RBB. Retrieved from https://keuangan.kontan.co.id/news/kinerja-bank-buku-1-dan-2-lesu-bankir-revisi-rbb.

22) Samad, S. (2013). Assessing the Contribution of Human Capital On Business Performance. International Journal of Trade, Economics and Finance, Vol. 4, No. 6, December 2013. 393-397.

23) Sauerman, J. (2016). Performance measures and worker productivity. IZA World of Labor, Institute for the Study of Labor (IZA), 260-260, May.

24) Sekaran, U., and Bougie, R., (2016). Research Methods for Business: A Skill-Building Approach. Chichester: John Wiley \& Sons. 
IJBE: Integrated Journal of Business and Economics

e-ISSN: 2549-3280

25) Sugiyono. (2013). Statistika Untuk Penelitian. Bandung: Alfabeta.

26) Sumual, T., Kawulur, A. F., Manaroinsong, T. (2017). Increasing Employee Productivity Through Human Capital and Organizational Capital. International Journal of Business and Management Invention (IJBMI), vol. 6, no. 9, 2017, pp. 16-21.

27) Tessema, D. A., (2014). The Impact of Human Capital On Company Performance Case of the Footwear Sector in Ethiopia. African Journals Online. Vol.6 No. 2 December 2014,76-103. 